\title{
Thermal properties and crystallization of iron phosphate glasses containing up to 25 wt \% additions of Si-, Al-, Na- and U-oxides
}

Diego O. Russo ${ }^{\mathrm{a}}$, Diego S. Rodríguez ${ }^{\mathrm{a}}$, Jesús Ma. Rincón L. , Maximina Romero ${ }^{\mathrm{b}}$, Carlos J.R. González Oliver ${ }^{\mathrm{a}, \mathrm{c}, \text {, }}$

${ }^{a}$ Centro Atómico Bariloche (CAB), Avenida E. Bustillo 9500, (8400) S. C. de Bariloche, (RN), Argentina

${ }^{\mathrm{b}}$ Instituto E. Torroja, CSIC c/ Serrano Galvache 4, Madrid 28033, Spain

${ }^{\mathrm{c}}$ Consejo Nacional de Investigaciones Científicas y Técnicas (C.O.N.I.C.E.T) Avda. Rivadavia 1917, CP 1033 AAJ, Buenos Aires, Argentina

\section{Abstract}

The thermal properties (expansion, $T_{\mathrm{g}}$ and $T_{\text {SOFT. }}$ ) of glasses, having 56-66\% $\mathrm{P}_{2} \mathrm{O}_{5}, 14.8-$ $34.2 \% \mathrm{Fe}_{2} \mathrm{O}_{3}$ and 2-25 wt $\%$ additions of $\mathrm{SiO}_{2}, \mathrm{Al}_{2} \mathrm{O}_{3}, \mathrm{Na}_{2} \mathrm{O}$ and $\mathrm{UO}_{2}$, were comparatively estimated from dilatometric measurements in similar conditions. The $T_{\mathrm{g}}$ reversibility was clearly verified by varying the heating rates between 1 and $5{ }^{\circ} \mathrm{C} \mathrm{min}^{-1}$. From linear equations fits of the various glass properties as functions of the six components it is suggested the iron, sodium and uranium oxides decrease the thermal expansion (for $50<T \leqslant 300^{\circ} \mathrm{C}$ ), $T_{\mathrm{g}}$ and $T_{\text {SOFT. }}$. From DTA/XRD analysis of three glasses it was confirmed the crystallization tendency decreased with increasing the $\mathrm{UO}_{2}$ level in the glasses. Leaching test data for two compositions containing $\mathrm{Na}_{2} \mathrm{O}$ suggest addition of $\mathrm{UO}_{2}$ increases the chemical durability of the related glass. The roles of $\mathrm{UO}_{2}, \mathrm{Na}_{2} \mathrm{O}$ and Fe-oxide species as structural components of the glass network are discussed.

\section{PACS}

61.43.Fs; 64.70.Pf; 65.60.+a; 61.66.Fn; 67.80.Gb; 28.41.Kw

\section{Keywords}

Chemical durability; Crystallization; X-ray diffraction; Glass melting; Glass formation; Glass transition; Glasses; SEM S100; Phosphates; Thermal properties

\section{Introduction}

Vitrification of industrial wastes has been considered in recent years as a good candidate for inertization and/or recycling of a wide range of wastes [1]. In this sense the vitrification of radioactive wastes is now recognized as the best way for immobilizing isotopes of high and medium activity, resulting from the nuclear power production and applications of nuclear technology in science and industries [2]. Several glassy matrices have been checked and 
investigated in the last years by using borosilicate, high silica and lead-iron-phosphate glasses [3] and/or basalt compositions [4], but recently it appeared that iron phosphate glasses are promising matrices for the immobilization of some isotopes [5], [6], [7], [8], [12],[13], [14], [15], [17], [18], [19], [20], [22], [23], [24] and [25].

Thus, Marasinghe et al. [12] had obtained $40 \mathrm{Fe}_{2} \mathrm{O}_{3}-60 \mathrm{P}_{2} \mathrm{O}_{5}$ glasses in the ratios of $\mathrm{Fe}^{2+} / \mathrm{Fe}_{\text {total }}<0.4$, because over this ratio they had difficulties in making this type of glasses. It seems that they are formed by a network of $\mathrm{Fe}^{2+}{ }_{(1-x)} \mathrm{Fe}^{3+}{ }_{(x)}\left(\mathrm{P}_{2} \mathrm{O}_{7}\right)_{2}$ groups with clusters of $\left(\mathrm{Fe}_{3} \mathrm{O}_{12}\right)^{16-}$, which are interconnected with the $\left(\mathrm{P}_{2} \mathrm{O}_{7}\right)^{4-}$ groups. They depict good durability due to the $\mathrm{P}-\mathrm{O}-\mathrm{Fe}$ bonds, but they crystallize phases like $\mathrm{Fe}_{3}\left(\mathrm{P}_{2} \mathrm{O}_{7}\right)_{2}$ at $650{ }^{\circ} \mathrm{C}$ after $24 \mathrm{~h}$ of heat treatment. Several X-rays and neutron diffraction, spectroscopical and mechanical resonance studies of these glasses were made to elucidate the structure and to obtain the elastic constants of such glasses [9], [12], [13], [14], [15] and [16]. It appears that the crystallization tendency and kinetics depend strongly on the oxidation states of iron [17], [18] and [19]. In the previous works [20], [22], [23] and [24], various Fe phosphate glasses like $\mathrm{M} 4\left(\sim 61 \% \mathrm{P}_{2} \mathrm{O}_{5}, \sim 26 \% \mathrm{Fe}_{2} \mathrm{O}_{3}\right)$ and $\quad \mathrm{M} 5 \quad\left(\sim 67 \% \mathrm{P}_{2} \mathrm{O}_{5}, \quad \sim 13.2 \% \mathrm{Fe}\right) \quad$ containing $\quad 13 \%\left(\mathrm{SiO}_{2}+\mathrm{Al}_{2} \mathrm{O}_{3}\right) \quad \mathrm{M} 4 \quad$ and $19.7 \%\left(\mathrm{SiO}_{2}+\mathrm{Al}_{2} \mathrm{O}_{3}+\mathrm{UO}_{2}\right)$ M5 were exploratory melted. Through DTA/TGA in air and XRD it was confirmed that M5 heated up to $800{ }^{\circ} \mathrm{C}$, had a negligible crystallization. At about $507{ }^{\circ} \mathrm{C}$ (M4) and $577{ }^{\circ} \mathrm{C}$ (M5), the powdered glasses clearly gained weight which was attributed to the oxidation of $\mathrm{Fe}^{2+}$ ions. In this work, thermal expansion and $T_{\mathrm{g}} / T_{\text {SOFT. }}$ data for six different iron phosphate glasses in the system $\mathrm{Na}_{2} \mathrm{O}-\mathrm{Fe}_{2} \mathrm{O}_{3}-\mathrm{Al}_{2} \mathrm{O}_{3}-\mathrm{SiO}_{2}-\mathrm{P}_{2} \mathrm{O}_{5}$ are reported, with/without additions of $\mathrm{U}_{3} \mathrm{O}_{8}$. It is aimed at elucidating what may be the effect of varying particular oxide components on such glass properties and how they could be incorporated into the glass structure.

\section{Materials and methods}

Six original batch compositions listed in Table 1 have been melted in a kanthal furnace model Deltech DT-31 by using sintered alumina crucibles after a previous calcination thermal treatment at $700{ }^{\circ} \mathrm{C}$ for $1 \mathrm{~h}$. The melting operation was carried out at $1250{ }^{\circ} \mathrm{C}$ in air atmosphere at ambient pressure for $2 \mathrm{~h}$. The liquid batch was poured over a steel mould and the glass pieces were heat treated for releasing stresses at $550{ }^{\circ} \mathrm{C}$ followed by slow cooling. The raw materials were $\mathrm{AlPO}_{4}\left(98 \%\right.$ pure) and/or $\mathrm{NH}_{4} \mathrm{H}_{2} \mathrm{PO}_{4}\left(99.5 \%\right.$ pure) CAAL (Brasil), $\mathrm{Fe}_{2} \mathrm{O}_{3}$ Berna (Argentina), $\mathrm{SiO}_{2}, \mathrm{Na}_{2} \mathrm{CO}_{3}$ Cicarelli (Argentina) and $\mathrm{U}_{3} \mathrm{O}_{8}(\mathrm{CAB})$. 
Table 1. Theoretical and measured chemical compositions of CAB1, CAB2, DR1, DR2, PFeOx and PFeUOx glasses

\begin{tabular}{|c|c|c|c|c|c|c|c|}
\hline \multicolumn{2}{|c|}{ Composition (wt $\%$ ) } & \multirow{2}{*}{ 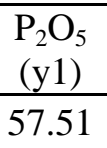 } & \multirow{2}{*}{$\begin{array}{c}\begin{array}{c}\mathrm{SiO}_{2} \\
(\mathrm{y} 2)\end{array} \\
-\end{array}$} & \multirow{2}{*}{ 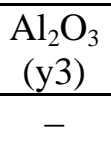 } & \multirow{2}{*}{$\begin{array}{c}\begin{array}{c}\mathrm{Fe}_{2} \mathrm{O}_{3} \\
(\mathrm{y} 4)\end{array} \\
42.49\end{array}$} & \multirow{2}{*}{$\begin{array}{c}\mathrm{Na}_{2} \mathrm{O} \\
(\mathrm{y} 5)\end{array}$} & \multirow{2}{*}{$\begin{array}{c}\begin{array}{c}\mathrm{UO}_{2} \\
(\mathrm{y} 6)\end{array} \\
-\end{array}$} \\
\hline CAB1 & Nominal & & & & & & \\
\hline & Exp. (EDS) & 63.42 & - & 2.43 & 34.15 & - & - \\
\hline \multirow[t]{2}{*}{ CAB2 } & Nominal & 61.50 & - & - & 34.08 & 4.41 & - \\
\hline & Exp. (EDS) & 65.81 & - & 3.30 & 27.28 & 3.60 & - \\
\hline \multirow[t]{3}{*}{ DR1 } & Nominal & 55.84 & - & - & 36.09 & - & 8.07 \\
\hline & Exp. (EDS) & 60.33 & - & 3.56 & 30.85 & - & 5.26 \\
\hline & $\begin{array}{l}\text { Fluorescence data plus traces } \\
\text { of } \mathrm{Cu}, \mathrm{Mn}, \mathrm{Zn}, \mathrm{Cr}, \mathrm{Ti}, \mathrm{Cl} \text { and } \mathrm{S}\end{array}$ & 62.7 & 0.29 & 2.4 & 29.4 & & 5.1 \\
\hline \multirow[t]{2}{*}{ DR2 } & Nominal & 54.26 & - & - & 30.06 & - & 15.68 \\
\hline & Exp. (EDS) & 56.58 & - & 3.47 & 26.24 & - & 13.71 \\
\hline \multirow[t]{3}{*}{ PFeOx } & Nominal & 60 & 7 & 5 & 20 & 8 & \\
\hline & Exp. bulk glass (EDS) & 62.49 & 7.61 & 6.11 & 16.41 & 7.37 & - \\
\hline & Exp. glass powder (EDS) & 55.31 & 7.00 & 8.51 & 16.78 & 12.41 & - \\
\hline \multirow[t]{3}{*}{ PFeUOx } & Nominal & 60 & 3 & 3 & 20 & 4 & 10 \\
\hline & Exp. bulk glass (EDS) & 59.99 & 5.69 & 6.18 & 14.77 & 6.41 & 6.94 \\
\hline & Exp. glass powder (EDS) & 58.71 & 3.17 & 8.84 & 14.03 & 6.76 & 8.50 \\
\hline
\end{tabular}

The chemical compositions were estimated with a EDS/Edax detector fitted to a SEM Philips 515 scanning electron microscope. The specimens were ground flat and polished with $5 \mu \mathrm{m}$ diamond paste and the energy data were collected for similar periods of time and maintained the electron current at $20 \mathrm{kV}$ accelerating voltage constant. The data were processed via the standardless mode of the Edax software. The errors in these estimations were about $\pm 2 \mathrm{wt} \%$ oxides.The X-rays fluorescence data for DR1 glass were measured with a Bruker SRS3400 apparatus.

The XRD (X-rays diffraction) patterns were measured with a Philips PW 1700 diffractometer at a wavelength of $\lambda_{\mathrm{CuK} \alpha}=1.54054 \AA$. The DTA and TGA runs were effected using a Netzsch STA-409 apparatus at a heating rate of $10{ }^{\circ} \mathrm{C} \min ^{-1}$ in static air atmosphere.

The linear thermal expansion (LTE) was measured with a differential vertical dilatometer (Theta Dilatronics II; USA) at heating rates $(h)$ of 5 and $1{ }^{\circ} \mathrm{C} \mathrm{min}^{-1}$ under oxygen flow. The alumina push rod exerted a $6 \mathrm{~g}$ load on the specimen $\left(L_{0} \sim 5 \mathrm{~mm}\right.$; block of $\left.5 \times 4 \times 4 \mathrm{~mm}\right)$. The reference was a block of alumina, and the dilatometer was calibrated by inserting a piece of high purity (optical fiber grade) silica glass block of $5 \mathrm{~mm}$ in thickness replacing the specimen and repeating the thermal cycle. The corrected data are quoted as $\Delta L / L_{0}=\left[L(T)-L_{0}\right] / L_{0}$, where $L_{0}$ is 
the initial height of the specimen. The errors in $\Delta L / L_{0}$ and Tmeasurements are less than $3 \%$ and $\pm 3{ }^{\circ} \mathrm{C}$, respectively.

\section{Results}

\subsection{Glass melting, chemical compositions and leaching tests}

The glass compositions quoted in Table 1 as [Exp.(EDS)] were estimated via EDS/SEM in the same conditions for all the glasses, making a comparative analysis of the effect of composition on the physico-chemical properties among the glasses possible. Even though, for $\mathrm{PFeOx}$ and PFeUOx some variations are noted in the analysis when the values for flat polished glass are compared to those for glass grains. Furthermore, it is noted that the fluorescence analysis gave $2.4 \mathrm{wt} \%$ more $\mathrm{P}_{2} \mathrm{O}_{5}, 1.4 \%$ less $\mathrm{Fe}_{2} \mathrm{O}_{3}, 1.1 \%$ less $\mathrm{Al}_{2} \mathrm{O}_{3}$ and $0.2 \%$ less $\mathrm{UO}_{2}$ than the EDS [Exp.(EDS)]-analysis for DR1 glass. Comparing the theoretical batch compositions with the measured ones, it is clear that some losses of $\mathrm{Fe}_{2} \mathrm{O}_{3}$ and $\mathrm{UO}_{2}$ occurred during melting. It is also clear that alumina was incorporated to the original glasses due to crucible corrosion in all glasses in proportions between 2.4 and $3.6 \mathrm{wt} \%$. Consequently, the analysis is affected by this addition, decreasing the $\mathrm{Fe}_{2} \mathrm{O}_{3}$ contents and increasing the $\mathrm{Al}_{2} \mathrm{O}_{3}$ content. For the phosphate glasses containing $\mathrm{Na}_{2} \mathrm{O}$, some losses in $\mathrm{Na}_{2} \mathrm{O}$ were obtained due to some volatilization, except for PFeUOx. This more complex glass PFeUOx, with six starting oxide components, increased its alumina level due to the crucible corrosion and decreased the $\mathrm{UO}_{2}$ content in the final glass affecting the values for the other components. The glass densities for the uranium containing glasses were 3.044 (DR1), 3.204 (DR2) and $2.964 \mathrm{~g} \mathrm{~cm}^{-3}$ (PFeUOx).

The final measured glass compositions have $\mathrm{P}_{2} \mathrm{O}_{5}$ and $\mathrm{Fe}_{2} \mathrm{O}_{3}$ contents ranging between $56 \%$ and $66 \%$ for $\mathrm{P}_{2} \mathrm{O}_{5}$ and between $14.8 \%$ and $34.2 \%$ for $\mathrm{Fe}_{2} \mathrm{O}_{3}$. These compositions may be tentatively regarded as P-/Fe-oxides matrices containing between 2 and $25 \mathrm{wt} \%$ additions of the remaining oxides in Table 1. Such additions were $2.43 \% \mathrm{Al}_{2} \mathrm{O}_{3} \mathrm{CAB} 1,6.9 \%\left(\mathrm{Al}_{2} \mathrm{O}_{3}+\mathrm{Na}_{2} \mathrm{O}\right)$ $\mathrm{CAB} 2,8.8 \%\left(\mathrm{Al}_{2} \mathrm{O}_{3}+\mathrm{UO}_{2}\right)$ DR1, 17.2\% $\left(\mathrm{Al}_{2} \mathrm{O}_{3}+\mathrm{UO}_{2}\right)$ DR2, $21.1 \%\left(\mathrm{SiO}_{2}+\mathrm{Al}_{2} \mathrm{O}_{3}+\mathrm{Na}_{2} \mathrm{O}\right) \mathrm{PFeOx}$ and $25.2 \%\left(\mathrm{SiO}_{2}+\mathrm{Al}_{2} \mathrm{O}_{3}+\mathrm{Na}_{2} \mathrm{O}+\mathrm{UO}_{2}\right)$ for PFeUOx. It is of interest to note that the ionic crystal radii $(\AA)$ for coordination number $\mathrm{CN}=6$ for the components present in these glasses are about $\mathrm{P}^{5+} 0.35, \mathrm{O}^{2-} 1.40, \mathrm{Si}^{4+} 0.40, \mathrm{Fe}^{2+} 0.77, \mathrm{Fe}^{3+} 0.65, \mathrm{U}^{4+} 0.89-0.97, \mathrm{U}^{5+} 0.79, \mathrm{Al}^{3+} 0.53$ and $\mathrm{Na}^{+} 1.02$ [10] and [11]. Therefore, for example, $\mathrm{U}^{4+}$ ions could be located in sites replacing $\mathrm{Na}^{+}$ions. It has been proposed for iron phosphate glasses (containing about 40 mole $\% \mathrm{Fe}_{2} \mathrm{O}_{3}$ ) showing enhanced chemical resistance towards aqueous corrosion that the $\mathrm{P}_{2} \mathrm{O}_{7}$ groups are joined by $\mathrm{Fe}^{3+}$ in tetrahedral/octahedral oxygen coordination [12], [13], [14], [15] and [25]. The 
larger $\mathrm{Fe}^{2+}$ in octahedral coordination would be located between the chains formed by $\mathrm{PO}_{4}$ groups and $\mathrm{Fe}^{3+}$ polyhedra, and so the $\mathrm{Fe}^{2+}$ ions can be considered as network modifiers. The enhanced chemical resistance is attributed to the formation of $\mathrm{Fe}-\mathrm{O} \_\mathrm{P}$ bonds.

As noted above these iron phosphate glasses are of interest since high dissolution power of, for instance, uranium oxide has been confirmed and that such charged matrices can be reasonably stable towards aqueous corrosion. In Fig. 1 are shown leaching tests[20] and [21] for $\mathrm{PFeOx}$ and PFeUOx glasses having, respectively, 16.41 and $14.77 \mathrm{wt} \% \mathrm{Fe}_{2} \mathrm{O}_{3}$. The rough parabolic fits were made only as guides to the eye. The lower leaching rate for PFeUOx as compared to that for $\mathrm{PFeOx}$ is noted. The main difference between the Exp.EDS compositions of these two glasses is that PFeUOx contains about $7 \mathrm{wt} \% \mathrm{UO}_{2}$ (Table 1), and this suggests that additions of $\mathrm{UO}_{2}$ increase the chemical durability of such complex glasses. This confirms the idoneity of this type of glassy matrices for the immobilization of uranium, though the relative stability in water is not probably high enough for the final recommendation of this matrix for retention of this element from radioactive wastes [5].

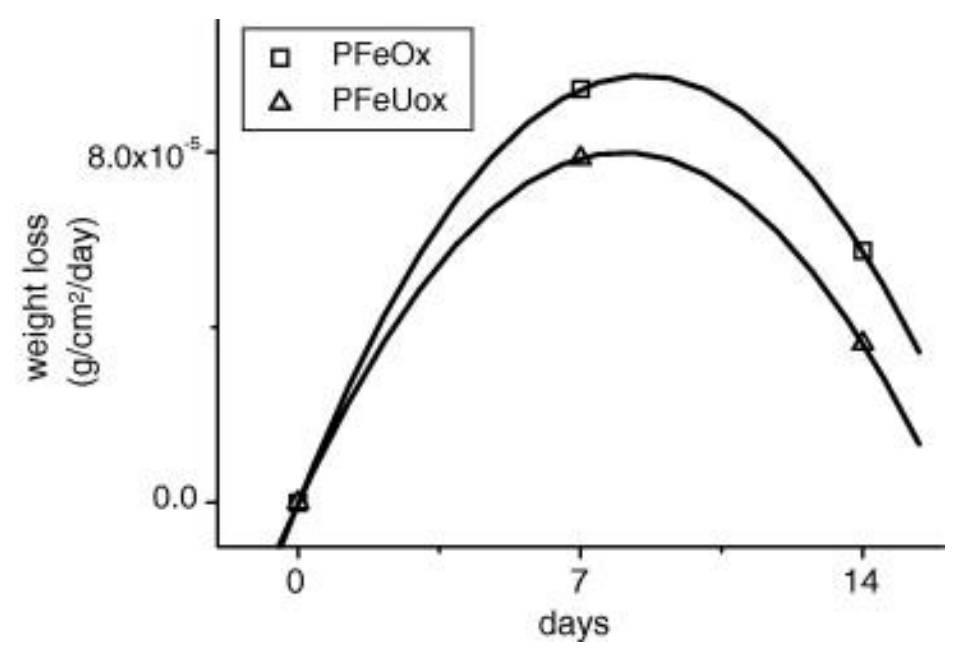

Fig. 1. Leaching (PTC) essays for PFeOx and PFeUOx glasses.

\subsection{XRD/DTA/TGA}

In Fig. 2 are shown the XRD curves for all the glasses except for PFeOx which was not determined. They are all amorphous and if carefully observed it appears that some scattering differences exist in both ranges (a) $24-25^{\circ}$ and (b) $40-80^{\circ}$ when CAB1/CAB2 (compositions not containing uranium) are compared to DR1/DR2/PFeUOx glasses. 


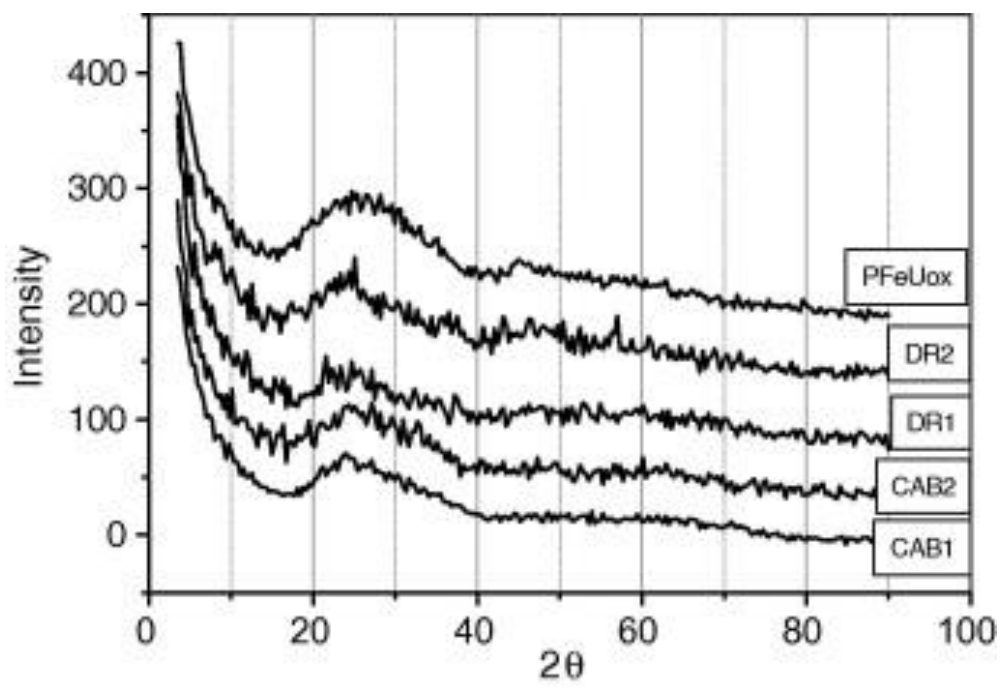

Fig. 2. XRD data for powdered CAB1, CAB2, DR1, DR2 and PFeUOx glasses.

For these iron-phosphate glasses, in fine powder form, it is not always possible to obtain clear DTA traces (for $\mathrm{O}_{2}$-containing atmospheres), with well-defined endothermic or exothermic peaks, perhaps owing to the fact that for certain compositions they are indeed difficult to be crystallized [20] and [22]. In Fig. 3 and Fig. 4 are shown the best traces obtained for $\mathrm{CAB} 1$ and $\mathrm{DR} 1$. In both the cases the endothermic peak corresponding to $T_{\mathrm{g}}$ was made clear by over imposing the dilatometric curve (see later) of each glass into the graph.

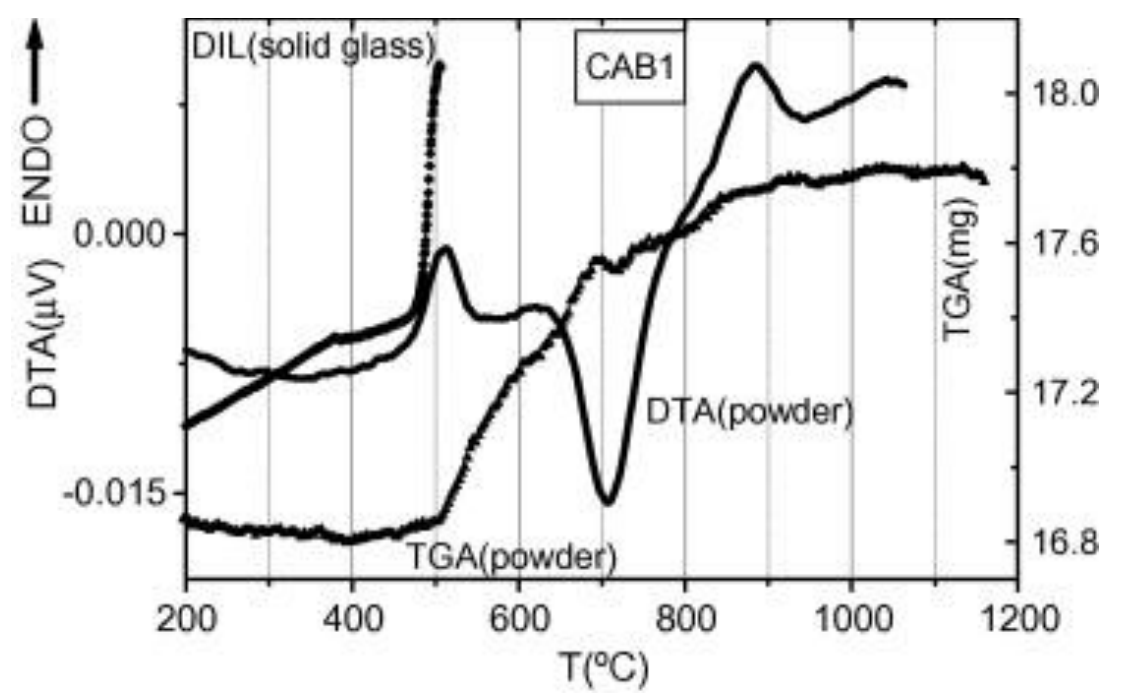

Fig. 3. DTA/TGA runs at $10^{\circ} \mathrm{C} \mathrm{min}^{-1}$ in air for $\mathrm{CAB} 1$ in powder form, and dilatometric curve (at 5.3 ${ }^{\circ} \mathrm{C} \min ^{-1}$ ) for solid glass CAB1. 


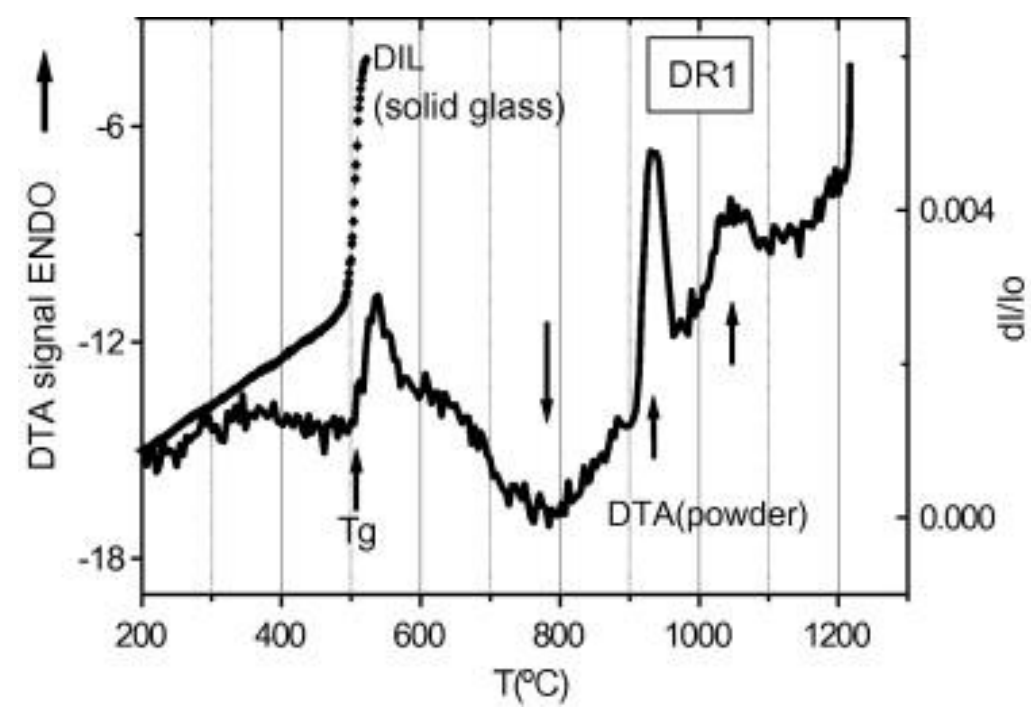

Fig. 4. DTA run $\left(10^{\circ} \mathrm{C} \mathrm{min}^{-1}\right)$ in air and dilatometric curve (at $\left.5.2{ }^{\circ} \mathrm{C} \mathrm{min}{ }^{-1}\right)$ under $\mathrm{O}_{2}$ flow for glass DR1.

For $\mathrm{CAB} 1$ it is clear enough that after about $650{ }^{\circ} \mathrm{C}$ the glass started to crystallize with exothermic peak-minimum at around $700{ }^{\circ} \mathrm{C}$ and that the precipitated phase (s) melted with endothermic peak-maximum at around $880^{\circ} \mathrm{C}$. For CAB1 it is also of interest to note that for $T \geqslant T_{\mathrm{g}}$ and more precisely for $T \geqslant 520^{\circ} \mathrm{C}$ the TGA curve shows very clearly that the glass started gaining weight. This could well correspond to the oxidation of $\mathrm{Fe}^{2+}$ ions into $\mathrm{Fe}^{3+}$ ones, as marked in [18] where for similar glasses (melted in air atmosphere for different temperatures and periods of time) the contents of both ions were measured via Mossbauer spectroscopy. For DR1 the crystallization peak-minimum is met at around $783^{\circ} \mathrm{C}$ and two melting peaks are obtained at 934 and $1045^{\circ} \mathrm{C}$ (see the arrows in Fig. 4). DR1 contains $1.2 \%$ more $\mathrm{Al}_{2} \mathrm{O}_{3}, 5.3 \%$ more $\mathrm{UO}_{2}$ and $3.3 \%$ less $\mathrm{Fe}_{2} \mathrm{O}_{3}$ than $\mathrm{CAB} 1$ and these compositional variations are taken as those responsible for the delayed crystallization detected for DR1 as compared to that for CAB1. Futhermore, for DR1 and DR2 heated up to about $780{ }^{\circ} \mathrm{C}$, the XRD traces (not shown here) showed the presence of $\mathrm{Fe} 2 \mathrm{Fe}\left(\mathrm{P}_{2} \mathrm{O}_{7}\right)_{2}$ (JCPDS 80-2315) and $\mathrm{U}\left(\mathrm{PO}_{3}\right)_{4}(\mathrm{JCPDS}$ 25-0997) in the bulk of the glasses. On the surfaces of the partially crystallized glasses, the crystalline phase $\mathrm{Fe}\left(\mathrm{PO}_{3}\right)_{3}$ (JCPDS 38-0109) was detected in addition to the two phases mentioned previously. The crystalline peak intensities for DR1 were slightly stronger than those for DR2. It should then be noted that at least part of the uranium component dissolved in the glass structure may be precipitated as, for instance, phosphate compounds and that the temperatures of the crystallization peaks can depend strongly on the $\mathrm{UO}_{2}$ level in the glasses. 


\subsection{Thermal expansion properties [ $T_{\mathrm{g}}, T_{\text {SOFT. }}$ and linear thermal expansion (LTE)]}

In Fig. 5, Fig. 6 and Fig. 7 are shown the LTE curves for the six glasses. The glass pieces were initially (T1) heated to $T_{\mathrm{SOFT}}$ at $5.3-5.5^{\circ} \mathrm{C} \mathrm{min}^{-1}$, (T2) cooled down to room temperature at $1{ }^{\circ} \mathrm{C} \mathrm{min}{ }^{-1}$ and (T3) heated rapidly $\left(5.2-6.2{ }^{\circ} \mathrm{C} \mathrm{min}^{-1}\right)$ up to $400{ }^{\circ} \mathrm{C}$ and finally continued the heating from 400 to $T_{\text {SOFT. }}$ at $1{ }^{\circ} \mathrm{C} \mathrm{min}^{-1}$ (T4).

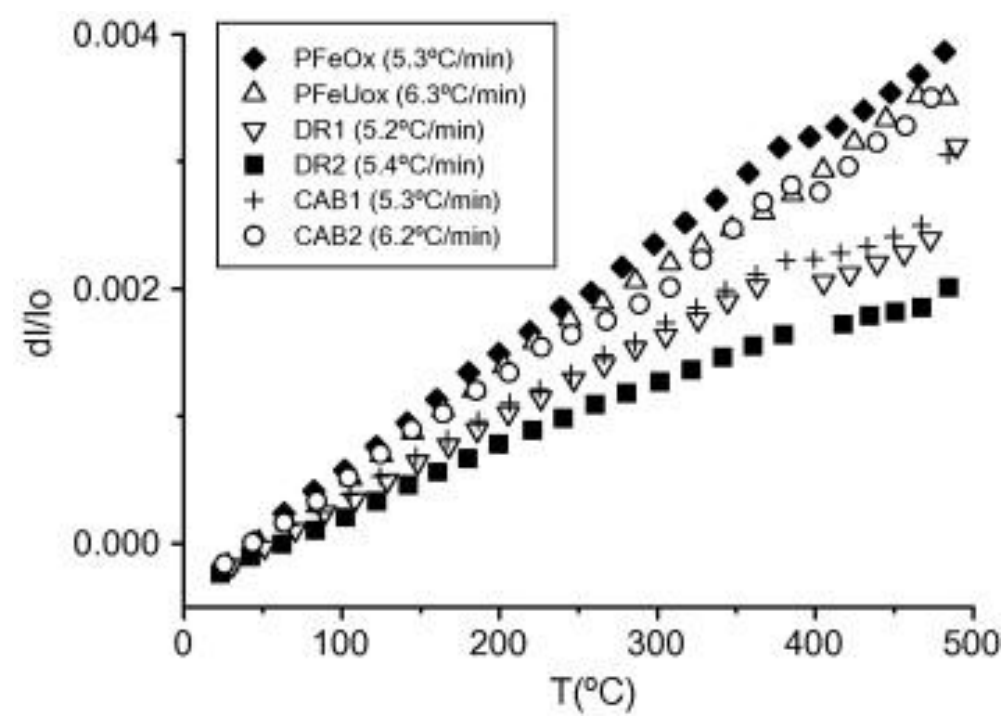

Fig. 5. Thermal expansion of glasses PFeOx, PFeUOx, DR1, DR2, CAB1 and CAB2 up to $500{ }^{\circ} \mathrm{C}$ under $\mathrm{O} 2$ flow at $5.2-6.3{ }^{\circ} \mathrm{C} \mathrm{min}{ }^{-1}$ heating rate. This corresponds to heat treatment $\mathrm{T} 3$ (see the text).

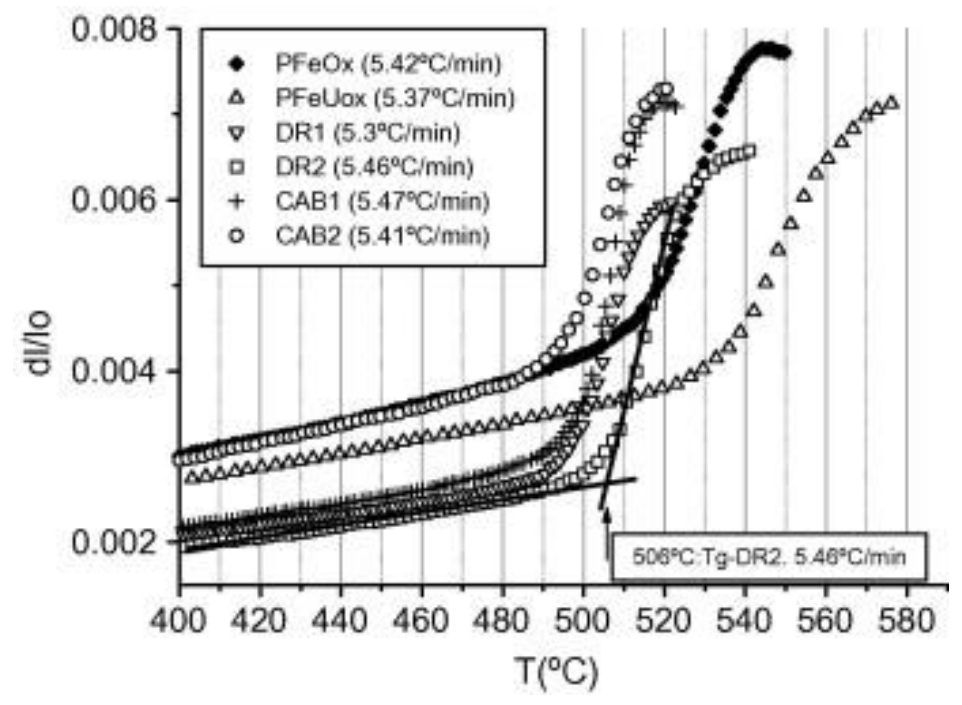

Fig. 6. Thermal expansion of glasses PFeOx, PFeUOx, DR1, DR2, CAB1 and CAB2 from $400{ }^{\circ} \mathrm{C}$ up to TSOFT. under $\mathrm{O}_{2}$ flow at $5.3-5.5^{\circ} \mathrm{C} \mathrm{min}{ }^{-1}$ heating rate. It corresponds to heat treatment $\mathrm{T} 1$ (see the text). 


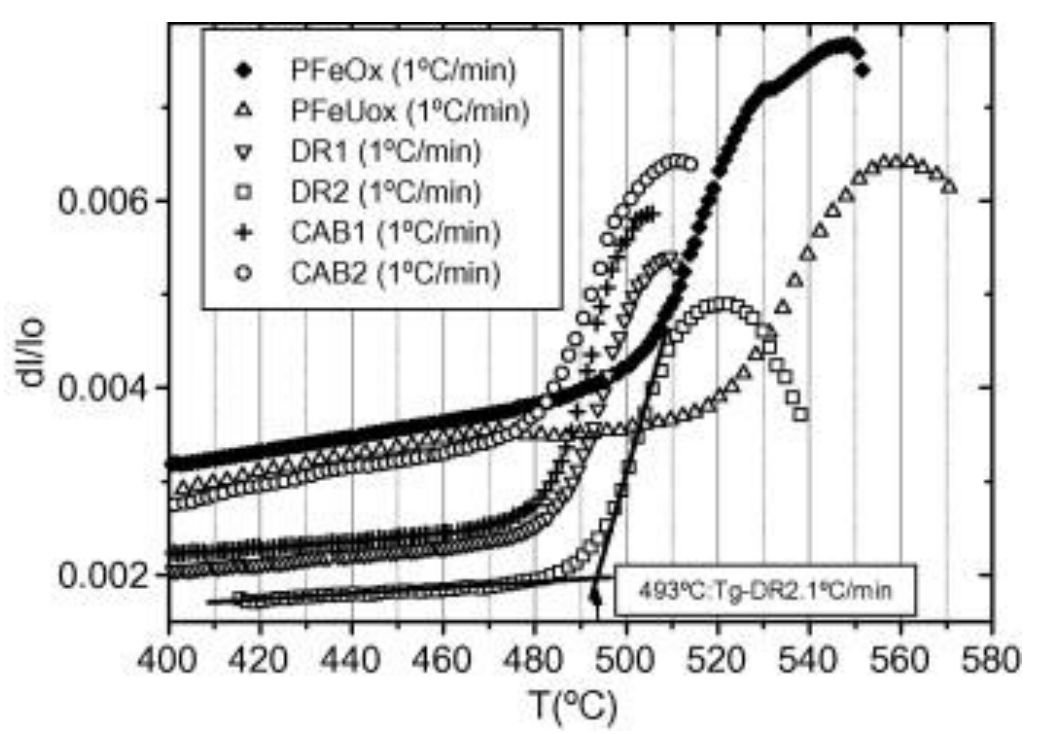

Fig. 7. Thermal expansion of glasses PFeOx, PFeUOx, DR1, DR2, CAB1 and CAB2 from $400{ }^{\circ} \mathrm{C}$ up to TSOFT. under $\mathrm{O}_{2}$ flow at $1{ }^{\circ} \mathrm{C} \mathrm{min}{ }^{-1}$ heating rate. This corresponds to heat treatment $\mathrm{T} 4$ (see the text).

It is quite evident that after a more or less linear expansion up to roughly $480-520{ }^{\circ} \mathrm{C}$ (depending on glass composition and heating rate; note also the change from cycle $\mathrm{T} 3$ to $\mathrm{T} 4$ at around $400{ }^{\circ} \mathrm{C}$ in Fig. 5), the LTE increases very markedly in the glass transition or transformation range. The linear thermal expansion coefficient $\alpha$ is defined as $\alpha=\left(\Delta L / L_{0}\right) / \Delta T$, where $\Delta T$ corresponds to the temperature range of the measurement. The coefficient $\alpha$ was estimated from the slope of lines interpolating the $\Delta L / L_{0}$ data (Table 2), and $T_{\mathrm{g}}$ (glass transition temperature) was estimated from the intersection of the two lines (for the low and high $T\left({ }^{\circ} \mathrm{C}\right)$ ranges) drawn as shown for glass DR2 in Fig. 6 and Fig. 7. From these curves in the glass transformation range, it may be advanced that the glasses behave as expected concerning the $T_{\mathrm{g}}$ reversibility. That is, with increasing $h$ the apparent $T_{\mathrm{g}}$ shifts to higher temperature and conversely. The dilatometric softening points or temperatures, $T_{\mathrm{SOFT}}$, correspond to the maxima shown in Fig. 6 and Fig. 7 (Table 2).

In Fig. 5 are shown the LTE curves for T3 cycle, and the $\alpha$-values ( Table 2) for the glasses are found to be in between those for $\mathrm{PFeOx}$ and DR2. It may be noted that the values $\Delta L / L_{0}\left(T\left({ }^{\circ} \mathrm{C}\right)\right)$ for $\mathrm{CAB} 1, \mathrm{DR} 1$ and $\mathrm{DR} 2$ are slightly curved downward, whereas those for PFeOx, CAB2 and PFeUOx oscillate around a straight line. In Fig. 7 are shown the $\Delta L / L_{0}$-data in the glass transformation range, for $h=1{ }^{\circ} \mathrm{C} \mathrm{min}^{-1}$ (cycle T4) for the same specimens ( Fig. 5 and Fig. 6), which were cooled in the dilatometer at $1^{\circ} \mathrm{C} \mathrm{min}^{-1}$. 
Diego O. Russo, Diego S. Rodríguez, Jesús Ma. Rincón L., Maximina Romero, Carlos J.R. González Oliver, Thermal properties and crystallization of iron phosphate glasses containing up to $25 \mathrm{wt} \%$ additions of Si-, Al-, Na- and U-oxides. Journal of Non-Crystalline Solids Volume 354, Issue 14, 1 March 2008, Pages 1541-1548; doi:10.1016/j.jnoncrysol.2007.08.044

Table 2. Expansion coefficient $\alpha, \mathrm{T}_{\mathrm{g}}$ and $\mathrm{T}_{\text {soft. }}$ values for CAB1, CAB2, DR1, DR2, PFeOx and PFeUOx glasses

\begin{tabular}{|c|c|c|c|c|}
\hline Code & $\alpha\left[\times 10^{-7}\left({ }^{\circ} \mathrm{C}^{-1}\right)\right]$ & $\mathrm{T}_{\mathrm{g}}\left({ }^{\circ} \mathrm{C}\right) 5.3-5.5^{\circ} \mathrm{C} / \mathrm{min} ; \mathrm{T} 1$ & $\mathrm{~T}_{\mathrm{g}}\left({ }^{\circ} \mathrm{C}\right) 1^{\circ} \mathrm{C} / \mathrm{min} ; \mathrm{T} 4$ & $\mathrm{~T}_{\text {soft. }}\left({ }^{\circ} \mathrm{C}\right)$ \\
\hline \multirow{3}{*}{ CAB 1} & $67.10\left[50-400{ }^{\circ} \mathrm{C}, 5.3{ }^{\circ} \mathrm{C} / \mathrm{min}\right], \mathrm{T} 3 ; * 67.39\left[50-300^{\circ} \mathrm{C}, 5.3\right.$ & \multirow{3}{*}{500} & & \\
\hline & $\left.{ }^{\circ} \mathrm{C} / \mathrm{min}\right], \mathrm{T} 3$ & & & $520,5^{\circ} \mathrm{C} / \mathrm{min}, \mathrm{T} 1$ \\
\hline & $36\left[400-470{ }^{\circ} \mathrm{C}, 1^{\circ} \mathrm{C} / \mathrm{min}\right], \mathrm{T} 4$ & & 483 & $504,1{ }^{\circ} \mathrm{C} / \mathrm{min}, \mathrm{T} 4$ \\
\hline \multirow{3}{*}{ CAB2 } & $78.20\left[50-400{ }^{\circ} \mathrm{C}, 6.2^{\circ} \mathrm{C} / \mathrm{min}\right], \mathrm{T} 3 ; * 83.94\left[50-230{ }^{\circ} \mathrm{C}\right.$, & \multirow{3}{*}{496} & & \\
\hline & $\left.6.2{ }^{\circ} \mathrm{C} / \mathrm{min}\right], \mathrm{T} 3$ & & & $520,5^{\circ} \mathrm{C} / \mathrm{min}, \mathrm{T} 1$ \\
\hline & $87.1\left[400-470{ }^{\circ} \mathrm{C}, 1^{\circ} \mathrm{C} / \mathrm{min}\right], \mathrm{T} 4$ & & 482 & $510,1^{\circ} \mathrm{C} / \mathrm{min}, \mathrm{T} 4$ \\
\hline \multirow{2}{*}{ DR1 } & $65.30\left[50-400{ }^{\circ} \mathrm{C}, 5.2^{\circ} \mathrm{C} / \mathrm{min}\right], \mathrm{T} 3 ; * 65.97\left[50-300^{\circ} \mathrm{C}\right.$, & \multirow{2}{*}{497} & & \\
\hline & $45\left[400-470{ }^{\circ} \mathrm{C}, 1^{\circ} \mathrm{C} / \mathrm{min}\right], \mathrm{T} 4$ & & 486 & $508,1^{\circ} \mathrm{C} / \mathrm{min}, \mathrm{T} 4$ \\
\hline \multirow{3}{*}{ DR2 } & $52.40\left[50-400{ }^{\circ} \mathrm{C}, 5.4^{\circ} \mathrm{C} / \mathrm{min}\right], \mathrm{T} 3 ; * 57.24\left[50-210^{\circ} \mathrm{C}\right.$, & \multirow{3}{*}{506} & & \\
\hline & $\left.5.4^{\circ} \mathrm{C} / \mathrm{min}\right], \mathrm{T} 3$ & & & $541,5^{\circ} \mathrm{C} / \mathrm{min}, \mathrm{T} 1$ \\
\hline & $28\left[417-470{ }^{\circ} \mathrm{C}, 1^{\circ} \mathrm{C} / \mathrm{min}\right], \mathrm{T} 4$ & & 493 & $519,1^{\circ} \mathrm{C} / \mathrm{min}, \mathrm{T} 4$ \\
\hline \multirow{3}{*}{$\mathrm{PFeOx}$} & $90.40\left[50-400{ }^{\circ} \mathrm{C}, 5.3^{\circ} \mathrm{C} / \mathrm{min}\right], \mathrm{T} 3 ; * 90.14\left[50-300^{\circ} \mathrm{C}, 5.3\right.$ & \multirow{3}{*}{515} & & \\
\hline & $\left.{ }^{\circ} \mathrm{C} / \mathrm{min}\right], \mathrm{T} 3$ & & & $546,5^{\circ} \mathrm{C} / \mathrm{min}, \mathrm{T} 1$ \\
\hline & $79\left[400-470{ }^{\circ} \mathrm{C}, 1^{\circ} \mathrm{C} / \mathrm{min}\right], \mathrm{T} 4$ & & 503 & $531-547,1^{\circ} \mathrm{C} / \mathrm{min}, \mathrm{T} 4$ \\
\hline \multirow{2}{*}{ PFeUox } & $84.70\left[50-400{ }^{\circ} \mathrm{C}, 6.3^{\circ} \mathrm{C} / \mathrm{min}\right], \mathrm{T} 3 ; * 87.52\left[50-300^{\circ} \mathrm{C}, 6.3\right.$ & \multirow{2}{*}{535} & & \\
\hline & $88-94\left[400-470{ }^{\circ} \mathrm{C}, 1^{\circ} \mathrm{C} / \mathrm{min}\right], \mathrm{T} 4$ & & $523-526$ & $559,1^{\circ} \mathrm{C} / \mathrm{min}, \mathrm{T} 4$ \\
\hline
\end{tabular}


For cycle T3, the three compositions: CAB1, DR1 and DR2, have close expansivities grouped in the range of the lower $\alpha$-values among the glasses, and it could be suggested that such glasses have similar glass structures. It is clear that $\alpha \mathrm{CAB} 1 \approx \alpha \mathrm{DR} 1>\alpha \mathrm{DR} 2$ and that for this series the $\mathrm{P}_{2} \mathrm{O}_{5}$ and $\mathrm{Fe}_{2} \mathrm{O}_{3}$ contents decrease and the $\mathrm{UO}_{2}$ level increases nearly monotonically (Table 1). Although $\alpha$ for $\mathrm{CAB} 2$ is clearly larger than that for CAB1, their $\left(T_{\mathrm{g}} ; T_{\text {SOFт.; }}\right.$; Table 2) values were quite similar. For cycle $\mathrm{T} 4$ (for $T \geqslant 400{ }^{\circ} \mathrm{C}$ and a heating rate of $1{ }^{\circ} \mathrm{C} \min ^{-1}$ ) also $\alpha \mathrm{CAB} 1 \approx \alpha \mathrm{DR} 1>\alpha \mathrm{DR} 2$, confirming somehow that these glasses have similar structures. However, the origin of the drop in the expansion coefficient for $T \geqslant 400{ }^{\circ} \mathrm{C}$ for these glasses is not yet known.

As noted above, the compositional variations of these glasses as well as their expansion and $T_{\mathrm{g}} / T_{\mathrm{SOFT}}$ behaviors are indeed quite large and it is difficult to elucidate any trend in properties caused by individual glass-components. There exists some collection of thermal expansion data for more or less similar glasses [25], [26] and [27], but it is somehow difficult to extrapolate and compare such values to the ones estimated in this work. For sodium-iron phosphate glasses, it was obtained that with increasing $\mathrm{Fe}_{2} \mathrm{O}_{3}$ and $\mathrm{Na}_{2} \mathrm{O}$ contents the dilatometric softening temperature increased and the thermal expansion coefficient and dissolution in $\mathrm{H}_{2} \mathrm{O}$ at $90{ }^{\circ} \mathrm{C}$ decreased [25].

Let us examine these effects in terms of linearly fitting $\alpha, T_{\mathrm{g}}$ and $T_{\text {SOFт. }}$ to the six glass compositions taken as weight fractions. Using Cramer's rule, the system of six equations with six variables can be solved. The $\alpha$-values marked with $*$ in Table 2 estimated in the range 50$210 / 300{ }^{\circ} \mathrm{C}$ for the data collected during cycle $\mathrm{T} 3$ at $5.2-6.3{ }^{\circ} \mathrm{C} \mathrm{min}^{-1}$ were used. The values for cycle T1 (Fig. 6) were used for the calculations of the dependencies of $T_{\mathrm{g}}$ and $T_{\text {SOFT. }}$ with composition. As a result, Eqs. (1), (2) and (3) were obtained.

$$
\begin{gathered}
\alpha=\left(4.4289 \times 10^{-5} * \mathrm{y} 1\right)+\left(-2.1989 \times 10^{-5} * \mathrm{y} 2\right)+\left(3.8843 \times 10^{-5} * \mathrm{y} 3\right)+\left(-6.5289 \times 10^{-}\right. \\
5 * \mathrm{y} 4)+\left(-11.7303 \times 10^{-5} * \mathrm{y} 5\right)+\left(-2.5917 \times 10^{-5} * \mathrm{y} 6\right) \\
\mathrm{T}_{\mathrm{g}}=(3324.0802 * \mathrm{y} 1)+(649.7220 * \mathrm{y} 2)+(-296.1695 * \mathrm{y} 3)+(-4688.6559 * \mathrm{y} 4)+(- \\
11181.2372 * \mathrm{y} 5)+(-980.1777 * \mathrm{y} 6) \\
\mathrm{T}_{\text {SOFT. }}=(4157.3949 * \mathrm{y} 1)+(671.0017 * \mathrm{y} 2)+(-536.5176 * \mathrm{y} 3)+(- \\
6160.734 * \mathrm{y} 4)+(-14370.6262 * \mathrm{y} 5)+(-1286.0233 * \mathrm{y} 6)
\end{gathered}
$$


For example, the $\left(\alpha, T_{\mathrm{g}}\right)$ values for CAB1 and $T_{\mathrm{SOFT}}$ for PFeUOx may be obtained through the following expressions:

$$
\begin{aligned}
\alpha_{\mathrm{CAB} 1}=( & \left.4.4289 \times 10^{-5} * 0.63423\right)+\left(3.8843 \times 10^{-5} * 0.0243\right)+\left(-6.5289 \times 10^{-}\right. \\
5 * 0.34147)= & 67.39 \times 10^{-7}\left({ }^{\circ} \mathrm{C}^{1}\right) \\
T_{\mathrm{g} \text { CABI }}= & (3324.0802 * 0.63423)+(-296.1695 * 0.0243) \\
& +(-4688.6559 * 0.34147) \\
= & 500^{\circ} \mathrm{C}, \text { and }, T_{\text {gSOFT.PFeUOx }} \\
= & (4157.3949 * 0.59993)+(671.0017 * 0.05692) \\
& +(-536.5176 * 0.06184)+(-6160.734 \\
& * 0.14773)+(-14370.6262 * 0.06414) \\
& +(-1286.0233 * 0.06944) \\
= & 578^{\circ} \mathrm{C}
\end{aligned}
$$

From Eqs. (1) and (2), the very strong influence of $\mathrm{Na}_{2} \mathrm{O}$ content on both $\alpha$ and $T_{\mathrm{g}}$ is noted. This contribution is negative for $\alpha$ and $T_{\mathrm{g}}$. The second more important contribution comes from the $\mathrm{Fe}_{2} \mathrm{O}_{3}$ content, being also negative for $\alpha$ and $T_{\mathrm{g}}$. Concerning $\alpha$, the third influence is shared between the $\mathrm{P}_{2} \mathrm{O}_{5}$ and $\mathrm{Al}_{2} \mathrm{O}_{3}$ contents which are both positive: i.e. the coefficient of thermal expansion is increased with the increase of such components. The $\mathrm{P}_{2} \mathrm{O}_{5}$ content is also the third contribution to $T_{\mathrm{g}}$ and it is positive. It is of interest to note that additions of $\mathrm{UO}_{2}$ decrease both $\alpha$ and $T_{\mathrm{g}}$, in the same way as $\mathrm{Na}_{2} \mathrm{O}$ and $\mathrm{Fe}_{2} \mathrm{O}_{3}$ do, but to a lesser extent. In summary, it can be suggested tentatively that $\alpha$ is increased by $\mathrm{P}_{2} \mathrm{O}_{5}$ and $\mathrm{Al}_{2} \mathrm{O}_{3}$ additions and it is decreased by $\mathrm{Na}_{2} \mathrm{O}, \mathrm{Fe}_{2} \mathrm{O}_{3}, \mathrm{UO}_{2}$ and $\mathrm{SiO}_{2} . T_{\mathrm{g}}$ is decreased by $\mathrm{Na}_{2} \mathrm{O}, \mathrm{Fe}_{2} \mathrm{O}_{3}$ and $\mathrm{UO}_{2}$ additions and it is increased by $\mathrm{P}_{2} \mathrm{O}_{5}$ and $\mathrm{SiO}_{2}$; the influence of $\mathrm{Al}_{2} \mathrm{O}_{3}$ is negligible. The trend for $T_{\text {SOFT. }}$ is approximately similar to that for $T_{\mathrm{g}}$.

The behavior of these six glasses in the transformation range is as expected for 'normal' silicate glasses exhibiting no phase-separation effects. That is, by decreasing the heating rate the $T_{\mathrm{g}}$ values decrease and the shapes of the $\Delta L / L_{0}$ vs. $T\left({ }^{\circ} \mathrm{C}\right)$ curves are similar for both $h$ of $\sim 5$ and $1{ }^{\circ} \mathrm{C} \min ^{-1}$. These curves (see Fig. 6 and Fig. 7) are smooth from $T_{\mathrm{g}}$ to $T_{\text {SOFT. with the }}$ exception of that for $\mathrm{PFeOx}$ at $1{ }^{\circ} \mathrm{C} \mathrm{min}{ }^{-1}$, which shows a short plateau at about $530{ }^{\circ} \mathrm{C}$ before $T_{\text {SOFT. }} \sim 548{ }^{\circ} \mathrm{C}$. The origin of such an effect for this composition is not yet known.

Attempting to clarify the type of glassy structure these glasses may have, it is relevant to study the behavior of these compositions also in the range from $T_{\mathrm{g}}$ to $T_{\mathrm{SOFT}}$, where a more 
'liquid-like' character would be expected. The slopes of the $\Delta L / L_{0}$ curves after the $T_{\mathrm{g}}$ break do change very markedly for these glasses ( Fig. 6 and Fig. 7). The calculated values for T1 cycle (Fig. 6) were $253.644 \times 10^{-6}\left(\mathrm{CAB} 1,500-514{ }^{\circ} \mathrm{C}\right), 169.644 \times 10^{-6}\left(\mathrm{CAB} 2, \quad 500-514{ }^{\circ} \mathrm{C}\right)$, $168.106 \times 10^{-6}\left(\mathrm{DR} 1, \quad 500-514^{\circ} \mathrm{C}\right), \quad 172.904 \times 10^{-6}\left(\mathrm{DR} 2, \quad 505-525^{\circ} \mathrm{C}\right)$, $131.122 \times 10^{-6}\left(\mathrm{PFeOx}, 517-539{ }^{\circ} \mathrm{C}\right)$ and $93.212 \times 10^{-6}{ }^{\circ} \mathrm{C}^{-1}\left(\mathrm{PFeUOx}, 534-564{ }^{\circ} \mathrm{C}\right)$. Again a $6 \times 6$ linear system may be solved using these new expansion independent terms and the following Equation was obtained:

$$
\begin{aligned}
& \alpha=\left(1.9217 \times 10^{-3} * \mathrm{y} 1\right)+\left(2.7684 \times 10^{-3} * \mathrm{y} 2\right)+\left(-7.1135 \times 10^{-3} * \mathrm{y} 3\right)+\left(-2.3202 \times 10^{-}\right. \\
& \left.{ }^{3} * \mathrm{y} 4\right)+\left(-6.3110 \times 10^{-3} * \mathrm{y} 5\right)+\left(-0.4291 \times 10^{-3} * \mathrm{y} 6\right)
\end{aligned}
$$

$$
\text { For example }: \begin{aligned}
\alpha_{\mathrm{CABI}}= & \left(1.921710^{3} * 0.63423\right) \\
& +\left(-7.113510^{-3} * 0.0243\right) \\
& +\left(-2.320210^{-3} * 0.34147\right) \\
= & 253.66 \times 10^{-6}\left(\mathrm{C}^{-1}\right)
\end{aligned}
$$

The negative influences of $\mathrm{Al}_{2} \mathrm{O}_{3}$ (very strong), $\mathrm{Na}_{2} \mathrm{O}$ (strong) and $\mathrm{Fe}_{2} \mathrm{O}_{3}$ (mild effect) on the expansion in the range $T_{\mathrm{g}}<T<T_{\text {SOFT. }}$ are noted; the contribution of $\mathrm{UO}_{2}$ is negligible. The positive contributions are for $\mathrm{P}_{2} \mathrm{O}_{5}$ and $\mathrm{SiO}_{2}$. Some of these effects are the opposite when compared to those for the glassy solid like $\alpha$ in the $T<T_{\mathrm{g}}$ range. Therefore, it appears that when the ion movements are triggered on (for $T>T_{\mathrm{g}}$ ), the behavior of the liquid is now significantly different when compared to that of the glass. The lowest apparent expansion obtained for PFeUOx liquid could be attributed to the strong glass complexity given by the $25.2 \%$ additions (to the P-/Fe-oxide matrix) of the other oxides; the main influences are given by the high $\mathrm{Al}_{2} \mathrm{O}_{3}$ and $\mathrm{Na}_{2} \mathrm{O}$ levels in the glass.

\section{Discussion}

Although these glass melts are reasonably fluid at $1200-1400{ }^{\circ} \mathrm{C}$ in air, making it possible to cast them properly, they exhibit losses of some compounds like $\mathrm{Fe}_{2} \mathrm{O}_{3}$ and $\mathrm{UO}_{2}$ and furthermore, they corrode nearly any oxide crucible used for melting [3] and [7]; note in [16]the authors mentioned that $x \mathrm{Fe}_{2} \mathrm{O}_{3}-(100-x) \mathrm{P}_{2} \mathrm{O}_{5}$ glasses were melted in covered Pt-crucibles. Recent melting trials in our laboratory, at about $1250{ }^{\circ} \mathrm{C}$ in air using alumina crucibles, gave only $75 \mathrm{wt} \%$ of glass (contaminated with $\mathrm{Al}_{2} \mathrm{O}_{3}$ ) as compared to the initial batch. The remaining 
$25 \%$ of glass in the crucible could only be removed by fluxing with K-nitrate/hydroxides at about $1000{ }^{\circ} \mathrm{C}$. These effects imply difficulties in obtaining the exact chemical composition variations for systematic studies. Also, as mentioned above, there are significant differences in chemical compositions between fluorescence and EDS data and it is recalled that acceptable chemical analysis data are needed for exact comparisons or predictions. Furthermore, as shown in detail [17], [18], [19], [20] and [22], the ratio $\mathrm{Fe}^{2+} / \mathrm{Fe}^{3+}$ can vary strongly depending on the melting temperature and time and on the glass composition. As these effects strongly control the crystallization kinetics, it is also important to precisely maintain the temperature, time and the $\mathrm{O}_{2}$-content over the melt before casting the related glasses.

The water-leaching tests [21] are of interest, but however, to better define the chemical resistance of such glasses full chemical durability assays should be performed. Comparing PFeUOx, with PFeOx, the increased durability of the former can be associated to the larger addition of $25.2 \%$ of extra oxides (with particular emphasis to the $\mathrm{UO}_{2}$ content) increasing the glass complexity as compared to that for PFeOx. It should also be noted that PFeUOx may possess a stronger structure than $\mathrm{PFeOx}$, as evidenced by the lower $\alpha$ and higher $T_{\mathrm{g}} / T_{\text {SOFT. }}$. (Table 2; Fig. 5, Fig. 6 and Fig. 7) and the lower expansion for $T>T_{\mathrm{g}}$. The leaching test for PFeUOx gives roughly twice as much ion concentration in the leachate when compared to roughly similar phosphate glasses or ARM-1 reference borosilicate glass [5]. However, it can be proposed that substantial improvements could be reached by modifying the PFeUOx composition, as it can be the case after replacing some of the $\mathrm{Na}_{2} \mathrm{O}$ with $\mathrm{Fe}_{2} \mathrm{O}_{3}, \mathrm{Al}_{2} \mathrm{O}_{3}$ or $\mathrm{UO}_{2}$. Furthermore, these glasses containing U-oxide should also be tested after heating in oxidizing atmospheres up to about $700{ }^{\circ} \mathrm{C}$ since in that way the $\mathrm{Fe}^{2+}$ ions are oxidized to $\mathrm{Fe}^{3+}$ and remain in that ionic form (probably due to the presence of $\mathrm{U}$ ions) after cooling to room temperature [22]. The glass durability can benefit from this since it has been noted that for higher $\mathrm{Fe}^{3+} / \mathrm{Fe}^{2+}$ ratios the chemical durabilities of iron-phosphate glasses increase [12].

As reported for CAB1, DR1 and DR2, the crystallization tendency appears to decrease by reducing the $\left(\mathrm{P}_{2} \mathrm{O}_{5}+\mathrm{Fe}_{2} \mathrm{O}_{3}\right)$ levels: $97.57 \mathrm{wt} \% \mathrm{CAB} 1,91.18 \% \mathrm{DR} 1$ and $82.82 \%$ DR2, and increasing the additions of the remaining oxides: $2.43 \%\left(\mathrm{Al}_{2} \mathrm{O}_{3}\right) \mathrm{CAB} 1,8.8 \%\left(\mathrm{Al}_{2} \mathrm{O}_{3}+\mathrm{UO}_{2}\right)$ DR1 and $17.2 \%\left(\mathrm{Al}_{2} \mathrm{O}_{3}+\mathrm{UO}_{2}\right) \mathrm{DR} 2$.

It is not known as to what crystalline phase (s) precipitated in CAB 1 at $T \leqslant 700{ }^{\circ} \mathrm{C}$ but such a phase apparently melted at $T \leqslant 880{ }^{\circ} \mathrm{C}$. For a glass $31 \mathrm{~mol} \% \mathrm{Fe}_{2} \mathrm{O}_{3} \cdot 69 \% \mathrm{P}_{2} \mathrm{O}_{5}$, crystallizations at $T \leqslant 640{ }^{\circ} \mathrm{C}$ and at $T \leqslant 800{ }^{\circ} \mathrm{C}$ of, respectively, $\mathrm{Fe}_{3}\left(\mathrm{P}_{2} \mathrm{O}_{7}\right)_{2}$ and $\mathrm{Fe}_{4}\left(\mathrm{P}_{2} \mathrm{O}_{7}\right)_{3}[12]$ were obtained. Then, for CAB1 it could be possible it crystallized also $\mathrm{Fe}_{3}\left(\mathrm{P}_{2} \mathrm{O}_{7}\right)_{2}$ such as the higher $\mathrm{T}$ obtained 
in the present work can be related to the $2.43 \% \mathrm{Al}_{2} \mathrm{O}_{3}$ in the glass. Such crystal phase $\mathrm{Fe}_{3}\left(\mathrm{P}_{2} \mathrm{O}_{7}\right)_{2}$ should contain $1 \mathrm{Fe}^{2+}$ and $2 \mathrm{Fe}^{3+}$ sites. For $\mathrm{CAB} 1$ (initial mass of $17 \mathrm{mg}$ ) from the TGA curve in Fig. 3, and assuming that the weight-gain at $T \geqslant 520{ }^{\circ} \mathrm{C}$ (amounting to $\sim 1 \mathrm{mg}$ ) is due to the oxidation of $\mathrm{Fe}^{2+}$ (into $\mathrm{Fe}^{3+}$ ions), $17 \% \mathrm{Fe}^{2+}$ and $83 \% \mathrm{Fe}^{3+}$ can be calculated thus supporting the possibility that $\mathrm{Fe}_{3}\left(\mathrm{P}_{2} \mathrm{O}_{7}\right)_{2}$ was precipitated in $\mathrm{CAB} 1$. The DTA run for CAB1 is also close to that for glass $\mathrm{F}-30-\mathrm{H}\left(70 \mathrm{~mol} \% \mathrm{P}_{2} \mathrm{O}_{5} \cdot 28 \% \mathrm{Fe}_{2} \mathrm{O}_{3} \cdot 2 \% \mathrm{Al}_{2} \mathrm{O}_{3}\right)$, which showed crystallization and melting peaks (DTA run under argon flow) at, respectively, 695 and $845^{\circ} \mathrm{C}$ [17], temperatures close to the ones in Fig. 3.

For glasses based on $60 \mathrm{~mol} \% \mathrm{P}_{2} \mathrm{O}_{5} \cdot 40 \% \mathrm{Fe}_{2} \mathrm{O}_{3}$ containing $\mathrm{UO}_{2}$, it was found [14] that only the $\mathrm{FeO}$ distances changed slightly, suggesting that $\mathrm{U}$ occupies voids in the FeOP network not altering the basic structure of the parent glass. It could be assumed that this is also valid for the present glass compositions. The property-composition fittings made above should be considered only as tentative ones owing to the very large variations in the chemical composition of the glasses and the complex expansion behavior for different $T$ ranges. For $50<T<210 / 300{ }^{\circ} \mathrm{C}$ [cycle T3], the negative contributions to the expansion produced by $\mathrm{Na}_{2} \mathrm{O}$, $\mathrm{Fe}_{2} \mathrm{O}_{3}$ and $\mathrm{UO}_{2}$ would suggest that at least some proportions of each of those elements should occupy similar sites in the glass network. For instance, such proportions could bond strongly or more symmetrically the phosphate chains producing the compositional effects simulated by Eq. (1). In such $T$ range, the lower expansion for $\mathrm{CAB} 1$ (compared to that for CAB2) could be attributed to the higher Fe content which would reduce $\alpha$, according to Eq. (1), even if CAB1 does not contain $\mathrm{Na}_{2} \mathrm{O}$. For $400<T<470{ }^{\circ} \mathrm{C}$ [cycle $\mathrm{T} 4$ ], this effect is apparently enlarged as $\mathrm{CAB} 1$ reduces further its $\alpha$ while for $\mathrm{CAB} 2$ (containing $\mathrm{Na}_{2} \mathrm{O}$ ) nearly no change in $\alpha$, is detected. Now, for $T_{\mathrm{g}}<T<T_{\text {SOFT. }}$, CAB1 expands much more than $\mathrm{CAB} 2$, and according to Eq. (4) such an effect can be explained by the higher $\mathrm{Al}_{2} \mathrm{O}_{3}$ content for $\mathrm{CAB} 2$ as compared to $\mathrm{CAB} 1$. The effect of $\mathrm{Na}_{2} \mathrm{O}$ and $\mathrm{Fe}_{2} \mathrm{O}_{3}$ contents in Eq. (4) are considerably diminished relative to the case corresponding to Eq. (1). Obviously, the presence of $\mathrm{Na}_{2} \mathrm{O}$ in $\mathrm{CAB} 2$ and its higher alumina content are responsible for the very different expansion behavior as compared to that for $\mathrm{CAB} 1$. It may be suggested that $\mathrm{Na}^{+}$goes into modifier positions but somehow remains chemically bonded to the phosphate chains and this situation applies up to $T_{\mathrm{SOFT}}$. Concerning the Fe ions and from the very high expansion for CAB1, for $T_{\mathrm{g}}<T<T_{\mathrm{SOFT}}$, it could be suggested that either $\mathrm{Fe}^{2+} \mathrm{OP}$ or $\mathrm{Fe}^{3+} \mathrm{OP}$ bonds are lost when the glass approaches $T_{\mathrm{g}}$ causing the increase in expansion. For other glasses not containing $\mathrm{Na}_{2} \mathrm{O}$, as DR1 and DR2, the situation is close to that for $\mathrm{CAB} 1$ and $\alpha \mathrm{DR} 2<\alpha \mathrm{DR} 1$, for $50<T<(210-300){ }^{\circ} \mathrm{C}$, can be explained by Eq. (1) noting the much higher $\mathrm{UO}_{2}$ level for DR2 as compared to that for DR1. Now, 
for $T_{\mathrm{g}}<T<T_{\text {SOFT, }}, \alpha \mathrm{DR} 1 \sim \alpha \mathrm{DR} 2$ which suggests similar liquids DR1 and DR2 with the $\mathrm{U}$ ions placed probably in voids of the liquid structure and being practically unbonded to the phosphate chains. For $T<T_{\mathrm{g}}$ the $\mathrm{U}$ ions can be in interstitial sites strongly bonding the phosphate chains.

As a final comment, it should be noted that for $\mathrm{PFeOx}$ the short plateau at about $530{ }^{\circ} \mathrm{C}$ and the lower expansion for $530 \leqslant T \leqslant 548{ }^{\circ} \mathrm{C}$ (Fig. $7 ; h=1{ }^{\circ} \mathrm{C} \min ^{-1}$ ) could be due to the oxidation of $\mathrm{Fe}^{2+}$ into $\mathrm{Fe}^{3+}$, which would mean that the liquid-like iron-phosphate structure may also be strengthened when iron is present as $\mathrm{Fe}^{3+}$ ions.

Summarizing, the present glass compositions based on P-/Fe-oxides, having some of them important additions of $\mathrm{Na}_{2} \mathrm{O}, \mathrm{Al}_{2} \mathrm{O}_{3}$, and $\mathrm{SiO}_{2}$, can dissolve significant quantities of $\mathrm{UO}_{2}$ and still give quite stable glasses from the chemical durability and crystallization points of view. This suggests that these matrices are relevant for the immobilization of $U$ radioactive wastes. From the basic science field, it is also made clear in this work that more systematic composition/property research is definitely needed to clearly sort out the final stability behavior of the present glasses containing $\mathrm{UO}_{2}$. In that sense, measurements of glass viscosities, particularly at low temperatures with penetration and beam bending viscometers or through the fiber elongation method, should be performed on these types of glasses. Such characterization was found to be very useful to assess glass structural changes for $T$ close to $T_{\mathrm{g}}$ for soda-limesilica glasses around the $\mathrm{Na}_{2} \mathrm{O} \cdot 2 \mathrm{CaO} \cdot 3 \mathrm{SiO}_{2}$ composition [28].

\section{Conclusions}

The thermal expansion, $T_{\mathrm{g}}$ and $T_{\text {SOFT. }}$ of six glasses, having 56-66\% $\mathrm{P}_{2} \mathrm{O}_{5}, 14.8-34.2 \%$ $\mathrm{Fe}_{2} \mathrm{O}_{3}$ and 2-25 wt $\%$ additions of $\mathrm{SiO}_{2}, \mathrm{Al}_{2} \mathrm{O}_{3}, \mathrm{Na}_{2} \mathrm{O}$ and $\mathrm{UO}_{2}$, were comparatively estimated from dilatometric measurements in similar conditions. The $T_{\mathrm{g}}$ reversibility was clearly verified by varying the heating rates between 1 and $5^{\circ} \mathrm{C} \mathrm{min}^{-1}$. From linear fits of the various glass properties as functions of the six oxide components, it is suggested that the iron, sodium and uranium oxides decrease the thermal expansion (for $50<T \leqslant 300{ }^{\circ} \mathrm{C}$ ), $T_{\mathrm{g}}$ and $T_{\text {SOFT. }}$. From fittings of the expansion data for $T>T_{\mathrm{g}}$, it is obtained that the main controlling oxide additions are those of $\mathrm{Al}_{2} \mathrm{O}_{3}$ and $\mathrm{Na}_{2} \mathrm{O}$ and the role of alumina content is reversed from the $T<T_{\mathrm{g}}$ to the $T>T_{\mathrm{g}}$ expansion ranges. It is suggested that $\mathrm{Na}^{+}$, some of the $\mathrm{Fe}$ ions (probably $\mathrm{Fe}^{2+}$ ) and $\mathrm{U}$ ions are placed in interstitial positions and are strongly bonding the phosphates chains for $T<300{ }^{\circ} \mathrm{C}$. For $T>T_{\mathrm{g}}$ it could be suggested that only $\mathrm{Na}^{+}\left(\right.$and $\left.\mathrm{Al}^{3+}\right)$ and perhaps $\mathrm{Fe}^{3+}$ remain well bonded to the phosphate structure. 
From DTA/XRD analysis of the three glasses, it was confirmed that the crystallization tendency decreased with increasing the $\mathrm{UO}_{2}$ level in the glasses. From DTA analysis of glasses $\mathrm{CAB} 1$ and DR1, it was obtained that the crystallization peaks shifted to higher temperatures, that is with increasing the $\mathrm{UO}_{2}$ and $\mathrm{Al}_{2} \mathrm{O}_{3}$ contents.

Leaching test data for two compositions ( $\mathrm{PFeOx}$ and $\mathrm{PFeUOx}$ ) containing $\mathrm{Na}_{2} \mathrm{O}$ suggests that the additions of $\mathrm{UO}_{2}$ increase the chemical durability of such complex glasses.

\section{Acknowledgments}

The authors thank Messrs C. Cotaro, E. Scerbo and J. Menghini [Centro Atómico Bariloche] for the EDS/Edax analysis and leaching tests; Messrs. M. Sanfilippo and A. Heredia for their help in sample preparation; and Dr R.D. Pérez (CEPROCOR, Córdoba) for the X-rays fluorescence analysis. The financial support of the Centro Atómico Bariloche Superconductivity Group, which allowed the purchase of the main parts of the dilatometer is acknowledged. Financial help of J. Ma. Rincón for stage at CAB supported by IAEA, Viena, is much appreciated as well as the financial support of Univ. Nac. de Cuyo and C.O.N.I.C.E.T.

This work is dedicated to the memory of Professor Peter Finlay James, who deceased on 2nd July, 2005.

\section{References}

1. F. Nicoletti and S. Hreglich, Inertisation of inorganic solid waste by vitrification; Proceedings of the 1st National Congress Valorisation and Recycling of Industrial Wastes; (Eds.), M. Pelino and G.C. Pellacani, E. Mucchi Editore, Italy (1998) 155-160.

2. M. Hidalgo, J. Ma. Rincón. Bol. Soc. Esp. Ceram. Vidr., 26 (1987), p. 227.

3. C.M. Jantzen. J. Non-Cryst. Solids, 84 (1986), p. 215.

4. J. Ma. Rincón, J. Cáceres, C. González Oliver, D.O. Russo, A. Petkova, H. Hristov. J. Therm. Anal. Calor., 56 (1999), p. 931.

5. M.G. Mesko, D.E. Day. J. Nucl. Mater., 273 (1999), p. 27.

6. D.E. Day, Z. Wu, C.S. Ray, P. Hrma. J. Non-Cryst. Solids, 241 (1998), p. 1.

7. T. Fukui, T. Ishinomori, Y. Endo, M. Sazarashi, S. Ono and K. Suzuki, Iron phosphate glass as potential waste matrix for high-level radioactive waste; WM 03 Conference, February 23-27, 2003, Tucson, AZ.

8. C-W Kim, D.E. Day. J. Non-Cryst. Solids, 331 (2003), p. 20. 
9. M. Ijjaali, G. Venturini, R. Gerardin, B. Malaman, C. Gleitzer. Eur. J. Solid State Inorg. Chem., 28 (1991), p. 983.

10. 'Introduction to ceramics'; W.D. Kingery, H.K. Bowen, D.R. Uhlmann, John Wiley. 1976, p. 58.

11. N.C. Sturchio, M.R. Antonio, L. Soderholm, S.R. Sutton, J.C. Brannon. Science, 281 (1998), p. 971

12. G.K. Marasinghe, M. Karabulut, C.S. Ray, D.E. Day, M.G. Shumsky, W.B. Yelon, C.H. Booth, P.G. Allen, D.K. Shuh. J. Non-Cryst. Solids, 222 (1997), p. 144.

13. A. Moguš-Milanković, B. Pivac, K. Furić, D.E. Day. Phys. Chem. Glasses, 38 (2) (1997), p. 74.

14. M. Karabulut, G.K. Marasinghe, C.S. Ray, G.D. Waddill, D.E. Day. J. Appl. Phys., 87 (5) (2000), p. 2185.

15. S.T. Reis, M. Karabulut, D.E. Day. J. Nucl. Mater., 304 (2002), p. 87.

16. K.H. Chang, T.H. Lee, L.G. Hwa. Chin. J. Phys., 41 (4) (2003), p. 414.

17. A. Moguš-Milanković, M. Rajić, A. Drašner, R. Trojko, D.E. Day. Phys. Chem. Glasses, 39 (2) (1998), p. 70.

18. C.S. Ray, X. Fang, M. Karabulut, G.K. Marasinghe, D.E. Day. J. Non-Cryst. Solids, 249 (1999), p. 1.

19. I.W. Donald, B.L. Metcalfe and R.S. Greedharee, Crystallization kinetics of sodium iron aluminophosphate glasses studied by DSC and XRD; Proceedings of the XIX International Congress Glass, 2 Extended Abstracts Scotland (2001) 64-65.

20. D.O. Russo, D.S. Rodríguez, M. Sterba, J.Ma.L. Rincón, y C.J.R. González Oliver. Jornadas Sam/Conamet/AAS Argentina (2001), p. 835.

21. ASTM standard test method for determining chemical durability of nuclear waste glasses: the product consistency test (PCT). Designation C 1285 - 94.

22. D.O. Russo, D.S. Rodriguez, N. Grumbaum, y C.J.R. González Oliver. Jornadas Sam/Conamet/Simposio Materia Argentina (2003), p. 995.

23. C.J.R. González Oliver, D.O. Russo and A.F. Craievich, Iron phosphate glasses and gels; Activity Reports, LNLS Brasil 26th April 2005. 
24. Ma.A. Villegas, J.Ma. Rincón L., D.O. Russo and C.J.R. González Oliver; Processing and characterization of vitreous matrices processed by melting and/or sol-gel for the immobilization of industrial and/or radioactive wastes; Varirei 2005 L’Aquila Italy 2005.

25. X. Yu, D.E. Day, G.J. Long, R.K. Brow. J. Non-Crystalline Solids, 215 (1997), p. 21.

26. A. Makishima, J.D. Mackenzie. J. Non-Crystalline Solids, 22 (1976), p. 305.

27. J.S. Jun, M.R. Cha, B.H. Jung, H.S. Kim. J. Kor. Ceram. Soc., 40 (11) (2003), p. 1127.

28. C.J.R. González Oliver, D.O. Russo, P.F. James. Phys. Chem. Glasses, 45 (2004), p. 100. 